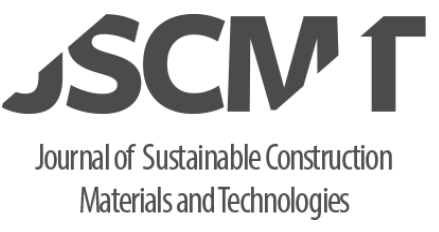

J Sustain. Construct. Mater. Technol. 4(2) (2019) 332-343 \begin{tabular}{c}
\hline \hline Journal of Sustainable \\
Construction Materials \\
and Technologies
\end{tabular}

www.eds.yildiz.edu.tr/jscmt

\title{
Life Cycle Costing and Assessment of Building Slab Materials
}

\author{
Moses Itanola ${ }^{\mathrm{a}, *}$, Najimu Saka ${ }^{\mathrm{a}}$ \\ ${ }^{a}$ Department of Quantity Surveying, Federal University of Technology, Akure, P.M.B 704, Nigeria
}

Manuscript Received January 1, 2019; Accepted September 10, 2019

\begin{abstract}
The selection process of material for slab construction must be well guided to ensure an effective and efficient slab. While numerous alternatives can be selected, some materials remain the dominant choice in the Nigerian construction industry. The usage of Concrete is now competing with eco-friendly materials such as Polystyrene and Hollow clay pot. This study researches into the life cycle cost of the three materials to determine the material with the lowest life cycle cost. It also assesses the environmental impacts posed by the production of the materials to the society. Cost data were retrieved from Design documents, Documented Bid Records, Bills of Quantities, Current documented prices, Maintenance schedules, and Slab Performance Models. Environmental Impact Assessment, structured interview, and Questionnaires were the collection instruments used to obtain assessment data. The analysis involved NPV discounting, Shadow pricing techniques, Sensitivity analysis, Descriptive statistics and Mean item scoring. The research discovered that although Concrete poses less cost on the slab users, Hollow clay pot slab possesses the lowest life cycle cost and differs from Polystyrene with a very close margin of less than $10 \%$. Major environmental impacts posed by the production of the materials were air pollution, badlands due to excessive mining, gas flaring, and environmental waste. The study then recommends that Hollow clay pot and Polystyrene serve as a better alternative for the commonly used Concrete and should, therefore, be adopted for slab construction.

Keywords: Slab; Concrete; Polystyrene; Hollow clay pot; Life cycle costing.
\end{abstract}

\section{Introduction}

The slab is a horizontal plate-like element which facilitates functional use of buildings and remains a technical aspect of the building [1]. The quality of a slab is highly dependent on the material it is composed of which is for achieving a hard, durable surface that is flat, relatively free of cracks and at proper grade and elevation [2]. The dominance of cast in-situ concrete for slab construction in the Construction Industry is gradually fading off with the evolution of new materials such as clay/mud, metals, timber, polystyrene etc. Divers' environmental challenges posed by the application of non-sustainable construction materials and techniques and higher cost of same in the recent time have made the quest for better and cheaper alternatives a crucial task in the provision of housing in Nigeria [3].

In the adoption of alternative eco-friendly building materials, the function, aesthetic and quality of work must not be compromised [3,4]. A major alternative eco-friendly material in use is the Concrete Expanded Polystyrene (CEP) [5]. Goodier [6] noted that the strength of a structure composed of expanded polystyrene determines to a large extent how well it can keep its monolithic nature thus making it an outstanding building material. CEPs are being increasingly and extensively used in building construction mostly because they are, energy efficient, light in weight, aesthetically attractive and can be easily erected [7].

Another of such material is the Hollow clay pot. Hollow clay slabs, a product of modern designs, now require

* Corresponding author. Tel.: +234-817-741-4790;
E-mail address: itanolam@ gmail.com

https://doi.org/10.29187/jscmt.2019.37 
less formwork, less reinforcement, and less concrete as a result of the space, holes, foams, and balls that are included in the slab [8]. Lai [9] also corroborated to the fact that the holes or voids, which are included in the slabs replace the ineffective concrete in the neutral zone of the slab, thus reducing the dead weight and increasing the slab efficiency.

Concrete is one of the most widely used construction material in the world and is used for floors, walls, slabs etc. [10]. Cast In-situ concrete slabs have been noted to be durable, damp resistance, low maintenance and fire resistant [11].

Life Cycle Cost Analysis (LCCA) is an indispensable technique that utilizes well-established principles of economic analyses to examine and evaluate the long-term performance of competing investment options [12]. It is an economic methodology for selecting the most cost-effective design alternative over a particular time frame, including construction, operation, maintenance, replacement, rehabilitation costs and residual value [13]. Although in LCCA environmental impacts such as those linked to emissions associated with building materials or operations are currently not considered, Life Cycle Assessment (LCA) examines a full range of inputs, emissions, effluents, and wastes that may or may not directly impact financial performance of a particular project, but which have implications for broader societies as well as the local, regional, and global environment [14].

Bribián, Capilla, and Usón [15] examined the Life cycle assessment of building materials through the comparative analysis of energy and environmental impacts and evaluation of the eco-efficiency improvement potential. They compared the most commonly used building materials with some eco-materials using three different impact categories. Dosumu and Adenuga [16] carried out an assessment of cost variation in solid and hollow floor construction in Nigeria. Their assessment revealed that the cost of in-situ solid floor slabs is greater than that of the hollow floor slab which indicates that solid slab construction is more expensive than hollow slab construction especially if the hollow slab is a one-way hollow floor and not a waffle floor.

While various research works are published and on-going on the life cycle assessment of Concrete [17-19] Hollow clay pot [20-23] and Polystyrene [24-28], no research has compared the adoption of these three materials, impacts on the society and their differential life cycle costs. Considering that the three materials remain the most dominant and evolving choice for use, evaluating the life cycle cost assessment of using these materials to determine the most effective for slab construction will impact positively the drive for an efficient construction industry.

\section{Methodology}

The research involved two-step analysis; Life cycle cost analysis (LCCA) and life cycle assessment (LCA). The elements required for a life cycle cost analysis includes Costs, Design Alternatives, Analysis Period, Discount Rates, and Shadow Pricing. The cost element consists of the Client costs and User costs as formulated by Ozbay, et al., [12]. Client Costs are the costs that are assumed by the owner as a result of putting the facility in service at the outset and maintaining its function at an acceptable level. Client costs consist of the costs of initial construction, rehabilitation and upgrading, periodic maintenance, engineering, and overhead. Initial construction, maintenance, and rehabilitation costs cover the costs of material, labour, machinery, and any other contingencies. These costs were estimated from Design documents, Documented Bid Records, Bills, Current documented prices, Structured Interview, Maintenance schedules, Slab Performance Models, and Forecast techniques.

Table 1. Distribution of client cost respondents

\begin{tabular}{llll}
\hline S/N & PROFESSION & NO & $\begin{array}{l}\text { PERCENTAGE } \\
(\%)\end{array}$ \\
\hline 1 & Civil Engineer & 3 & 15 \\
2 & Structural Engineer & 2 & 10 \\
3 & Architect & 4 & 20 \\
4 & Project Manager & 2 & 10 \\
5 & Builder & 2 & 10 \\
6 & Facility Manager & 1 & 5 \\
7 & Quantity Surveyors & 6 & 30 \\
& TOTAL & 20 & 100 \\
\hline
\end{tabular}

User costs are the costs encountered by the project users. These costs generally occur during the lifetime of the project. One of such is the loss recorded by the user because of evacuation for maintenance. Also, the 
majority of these costs are intangibles

Table 2. Distribution of respondents for User cost.

\begin{tabular}{llll}
\hline S/N & USERS CATEGORY & FREQUENCY & $\begin{array}{l}\text { PERCENTAGE } \\
(\%)\end{array}$ \\
\hline 1 & Concrete slab only & 11 & 55 \\
2 & Hollow pot only & 0 & 0 \\
3 & Polystyrene only & 0 & 0 \\
4 & Concrete and Hollow pot & 6 & 30 \\
5 & Concrete and Polystyrene & 1 & 5 \\
6 & Hollow pot and Polystyrene & 0 & 0 \\
& Concrete, Hollow pot and & & 10 \\
7 & Polystyrene & 2 & 100 \\
\hline
\end{tabular}

Life cycle assessment involved empirical inquiry to identify the various effects of the materials on the environment. A study was made into the production and post-production processes involved in the materials. The effects discovered for polystyrene includes Air pollution, Water pollution, Global warming potential, and Volume of solid waste [29, 24, \& 25]. For Hollow clay pot, Land use, Air pollution, and Energy content [20-23, $30, \& 31]$. For concrete, Air pollution, Global warming potential, and Energy content [17, 18, \& 32]. The data was gotten from Environmental Impact Assessment, Structured Interview, and Questionnaires. A total of 140 respondents were questioned. This includes construction professionals, users or occupants and workers or residents of the environment of the production of these materials. The data collection channel was designed to accommodate the various aspects of individuals involved in the production, usage, and disposal of these materials.

Table 3. Distribution for Life cycle assessment respondents

\begin{tabular}{lll}
\hline S/N & RESPONDENTS & FREQUENCY \\
\hline 1 & Workers and residents of Polystyrene factories & 20 \\
2 & $\begin{array}{l}\text { Workers and residents of Crude oil refinery } \\
\text { environments. }\end{array}$ & 20 \\
3 & Workers and residents of Clay pot industries & 10 \\
4 & Workers and residents of Clay exploration & 10 \\
5 & environments & 20 \\
6 & Workers and residents of Cement factories & 20 \\
\hline
\end{tabular}

For LCCA, analysis done includes Shadow pricing, NPV discounting and Uncertainty check using Sensitivity analysis. For LCA, analysis done includes Descriptive statistics using Mean Item scoring. Since the LCCA project-level secondary analysis intends to evaluate project alternatives that projects equal categorical benefits but requires unequal costs, the Net Present Value (NPV) is considered the appropriate indicator for comparing the differential economic worth of projects [12].

$N P V C=\sum_{t=0}^{T} \frac{C_{t}}{(1+d)^{t}}$

Where;

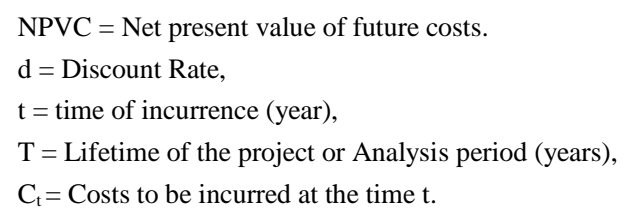

Rehabilitation period for hollow clay pot slab and polystyrene slab were assumed to occur at a lesser time interval in comparison to concrete slab because they are lightweight. The analysis period adopted for this study is 50years. 
Table 5. Client cost calculation for Concrete Slab

\begin{tabular}{|c|c|c|c|c|}
\hline YEARS & CONCRETE & $\begin{array}{l}\text { CLIENT } \\
\text { COST } \\
(\#) \\
\end{array}$ & $\begin{array}{c}\text { NPV } \\
\text { DISCOUNT } \\
\text { FACTOR }\end{array}$ & $\begin{array}{l}\text { DISCOUNTED } \\
\text { CLIENT COST } \\
(\$)\end{array}$ \\
\hline 0 & $\begin{array}{l}\text { Initial Construction Cost } \\
\text { Engineering / Admin }\end{array}$ & $55,800.78$ & 1.0000 & $55,800.78$ \\
\hline 0 & cost & $2,790.04$ & 1.0000 & $2,790.04$ \\
\hline 10 & Rehabilitation 1 & $2,769.15$ & 0.2829 & 783.28 \\
\hline 20 & Rehabilitation 2 & $2,935.30$ & 0.0800 & 234.85 \\
\hline 30 & Rehabilitation 3 & $3,156.83$ & 0.0226 & 71.44 \\
\hline 40 & Rehabilitation 4 & $3,322.98$ & 0.0064 & 21.27 \\
\hline 50 & Salvage value & -549.87 & 0.0018 & -1.00 \\
\hline & & & TOTAL (NPV) & $59,700.68$ \\
\hline
\end{tabular}

In table 5 above, Rehabilitation plans for the concrete slab reflect a 10 years' interval and at the end of the 50 years' usage life, the salvage value of the slab is calculated and deducted.

Table 6. Client cost calculation for Hollow clay pot slab

\begin{tabular}{lllll}
\hline & & $\begin{array}{l}\text { CLIENT } \\
\text { YOST } \\
(\text { YEARS }\end{array}$ & $\begin{array}{l}\text { NPV } \\
\text { DISCOUNT } \\
\text { FACTOR }\end{array}$ & $\begin{array}{l}\text { DISCOUNTED } \\
\text { CLIENT COST } \\
(\mathbf{N})\end{array}$ \\
\hline 0 & HOLLOW CLAY POT & $\begin{array}{l}\text { Initial Construction Cost } \\
0\end{array}$ & $\begin{array}{l}38,032.94 \\
\text { Engineering / Admin cost }\end{array}$ & $\begin{array}{l}3,422.96 \\
1.0000\end{array}$ \\
9 & Rehabilitation 1 & $1,900.17$ & 0.0000 & $38,032.94$ \\
18 & Rehabilitation 2 & $1,938.17$ & 0.1030 & $3,422.96$ \\
27 & Rehabilitation 3 & $1,976.18$ & 0.0331 & 609.83 \\
36 & Rehabilitation 4 & $2,014.18$ & 0.0106 & 69.32 \\
45 & Rehabilitation 5 & $2,052.18$ & 0.0034 & 21.37 \\
50 & Salvage value & -387.40 & 0.0018 & 6.99 \\
& & & TOTAL (NPV) & $\mathbf{4 2 , 3 5 8 . 3 4}$ \\
\hline
\end{tabular}

In table 6 above, Rehabilitation plans for the Hollow pot slab reflect a 9 years' interval and at the end of the 50 years' usage life, the salvage value of the slab is calculated and deducted.

Table 7. Client cost calculation for Polystyrene slab.

\begin{tabular}{lllll}
\hline & & $\begin{array}{l}\text { CLIENT } \\
\text { COST } \\
\text { YEARS }\end{array}$ & $\begin{array}{l}\text { NPV } \\
\text { DISCOUNT } \\
\text { FACTOR }\end{array}$ & $\begin{array}{l}\text { DISCOUNTED } \\
\text { CLIENT COST } \\
(\mathrm{N})\end{array}$ \\
\hline 0 & POLYSTYRENE & $41,416.44$ & 1.0000 & $41,416.44$ \\
0 & Initial Construction Cost & 1.0000 & $3,727.48$ \\
9 & Engineering / Admin cost & $3,727.48$ & 0.3209 & 663.12 \\
18 & Rehabilitation 1 & $2,066.22$ & 0.1030 & 217.07 \\
27 & Rehabilitation 2 & $2,107.54$ & 0.0331 & 71.03 \\
36 & Rehabilitation 3 & $2,148.87$ & 0.0106 & 23.23 \\
45 & Rehabilitation 4 & $2,190.19$ & 0.0034 & 7.60 \\
50 & Rehabilitation 5 & $2,231.52$ & 0.0018 & -0.32 \\
& Salvage value & -174.93 & TOTAL (NPV) & $\mathbf{4 6 , 1 2 5 . 6 5}$ \\
\hline
\end{tabular}

In table 7 above, Rehabilitation plans for the Polystyrene slab reflect a 9 years' interval and at the end of the 50 years' usage life, the salvage value of the slab is calculated and deducted. From Tables 5, 6, 7, the Initial construction and Engineering or Administrative cost of each alternative are accounted for at the start of the useful life of the material. The discounting factor for the two cost remains unchanged because the costs are not 
incurred as a futuristic amount.

The intangible user costs that have been accounted for in slabs are vibration transfer, sound penetration, heat gain or loss, liquid penetration, and maintenance evacuation costs [33-38, 12]. These costs generally occur during the lifetime of the project. User costs are valued differently during the normal operation and work-zone operation of the facility.

Table 8. User costs of Concrete, Hollow clay pot, and Polystyrene slab.

\begin{tabular}{|c|c|c|c|c|c|c|c|}
\hline No & Element & Concrete & $\begin{array}{l}\text { Discounted } \\
\text { Annual } \\
\text { Cost }\end{array}$ & $\begin{array}{l}\text { Hollow } \\
\text { Clay Pot } \\
\end{array}$ & $\begin{array}{l}\text { Discounted } \\
\text { Annual } \\
\text { Cost }\end{array}$ & Polystyrene & $\begin{array}{l}\text { Discounted } \\
\text { Annual } \\
\text { Cost } \\
\end{array}$ \\
\hline 1 & $\begin{array}{l}\text { Vibration } \\
\text { transfer } \\
\text { Sound }\end{array}$ & $109,500.00$ & $812,048.45$ & $166,987.50$ & $1,238,373.89$ & $164,250.00$ & $1,218,072.68$ \\
\hline 2 & $\begin{array}{l}\text { penetration } \\
\text { Heat gain }\end{array}$ & $82,125.00$ & $609,036.34$ & $85,775.00$ & $636,104.62$ & $73,000.00$ & $541,365.64$ \\
\hline 3 & $\begin{array}{l}\text { or loss } \\
\text { Liquid }\end{array}$ & $164,250.00$ & $1,218,072.68$ & $154,395.00$ & $1,144,988.32$ & $147,825.00$ & $1,096,265.41$ \\
\hline \multirow[t]{2}{*}{4} & $\begin{array}{l}\text { penetration } \\
\text { TOTAL }\end{array}$ & $61,593.75$ & $\begin{array}{l}456,777.25 \\
\mathbf{3 , 0 9 5 , 9 3 4 . 7 3}\end{array}$ & $68,437.50$ & $\begin{array}{l}507,530.28 \\
\mathbf{3 , 5 2 6 , 9 9 7 . 1 1}\end{array}$ & $67,068.75$ & $\begin{array}{l}497,379.68 \\
\mathbf{3 , 3 5 3 , 0 8 3 . 4 0}\end{array}$ \\
\hline & $\operatorname{cosT} / \mathrm{M}^{3}$ & & $34,284.99$ & & $39,058.66$ & & 37,132.71 \\
\hline
\end{tabular}

In table 8 above, Hollow clay pot slab incurs the highest cost on users of the slab when shadow pricing technique is used to evaluate the intangible costs incurred by users of the slab.

\subsection{Life Cycle Assessment}

Quantifying environmental impacts as well as estimating potential reductions in life cycle assessment has no generally adopted method. For the purpose of this research, the method for evaluating the environmental impact is descriptive statistics using tables and charts.

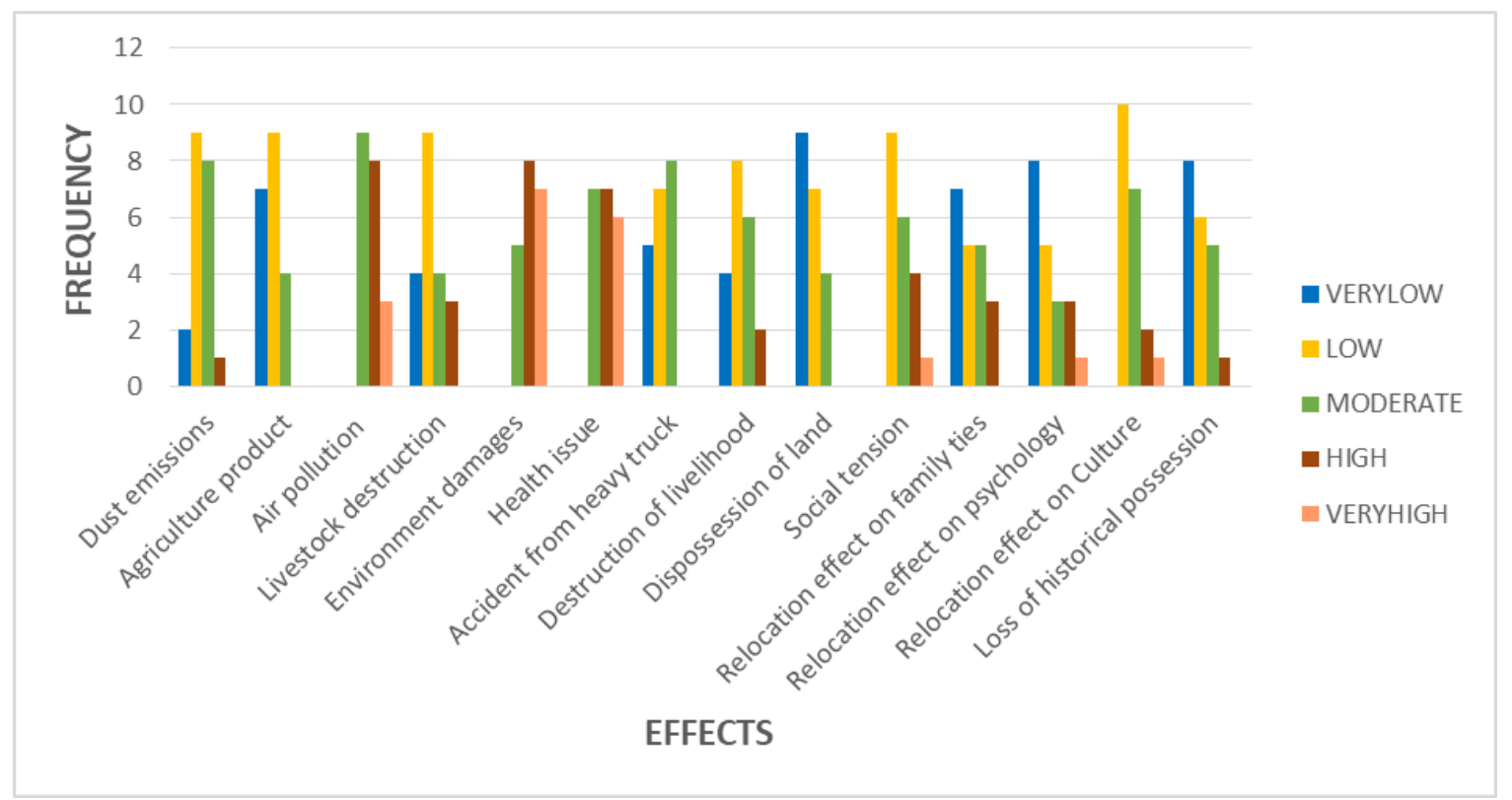

Fig 1 Distribution of effect of Polystyrene factories on the society.

Figure 1 above reveals the effect of polystyrene factories on the people living close to the plant. The effect is then ranked according to their mean item score. From the survey, Environment waste is the notable highest 
overall effects that the society would have to do with when polystyrene factories are located with a mean score of (4.1). Health issues and air pollution were ranked low by the respondents.

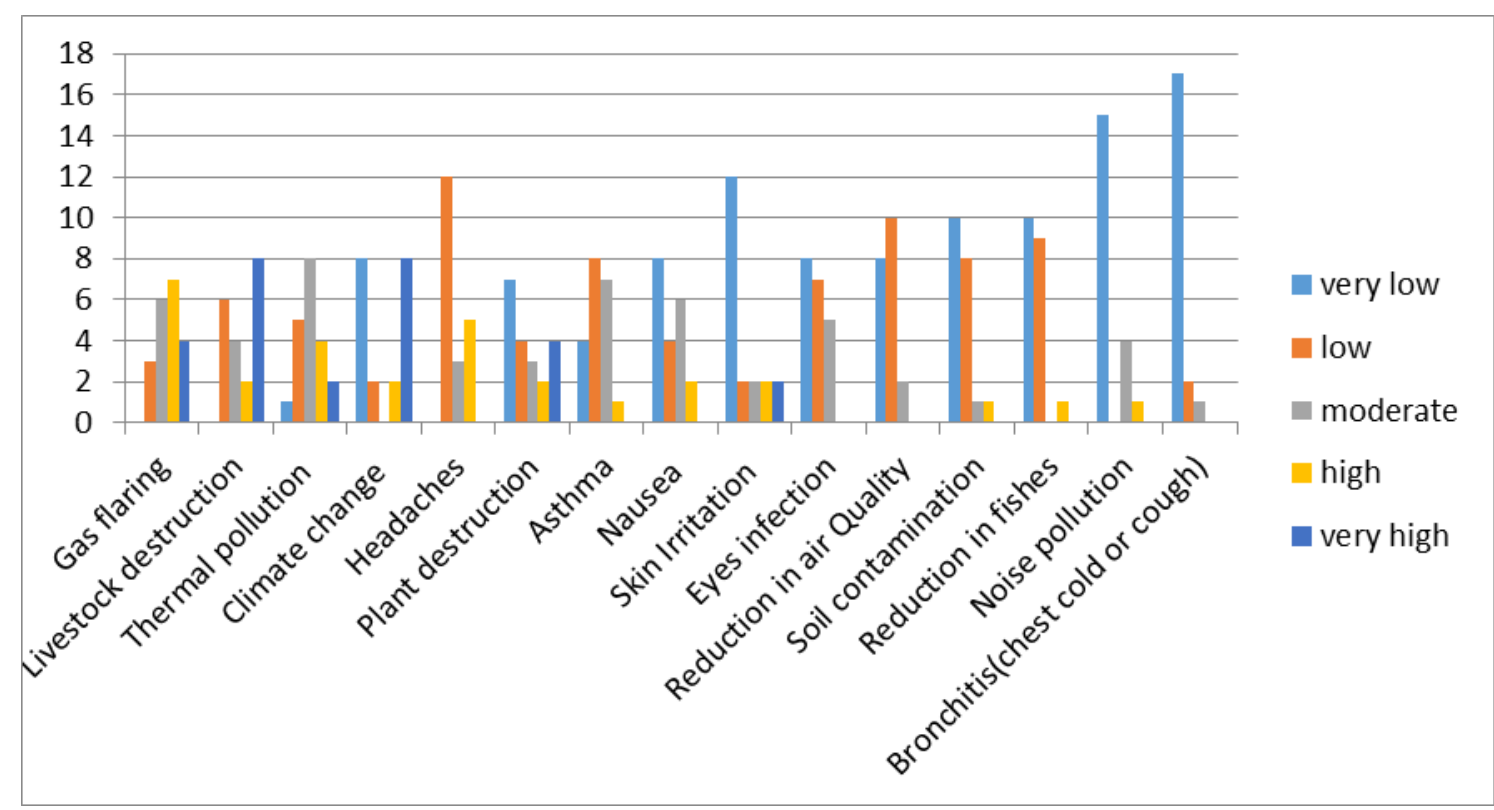

Fig. 2 Distribution of effect of a Crude oil refinery to the society.

Figure 2 above reveals the effect of the refinery on the people living close to the plant. The effect is then ranked according to their mean item score. From the survey, gas flaring and Livestock destruction are the notable highest overall effects that individual would have to do with over the entire life of the project with a mean score of (3.6). An estimated mean score of (3.05) was seen as the third notable effect from the refinery for thermal pollution. Effect resulting from Reduction in fishes, noise pollution and Bronchitis (chest cold or a cough) are ranked with the lowest mean score of $1.60,1.55$ and 1.20 respectively

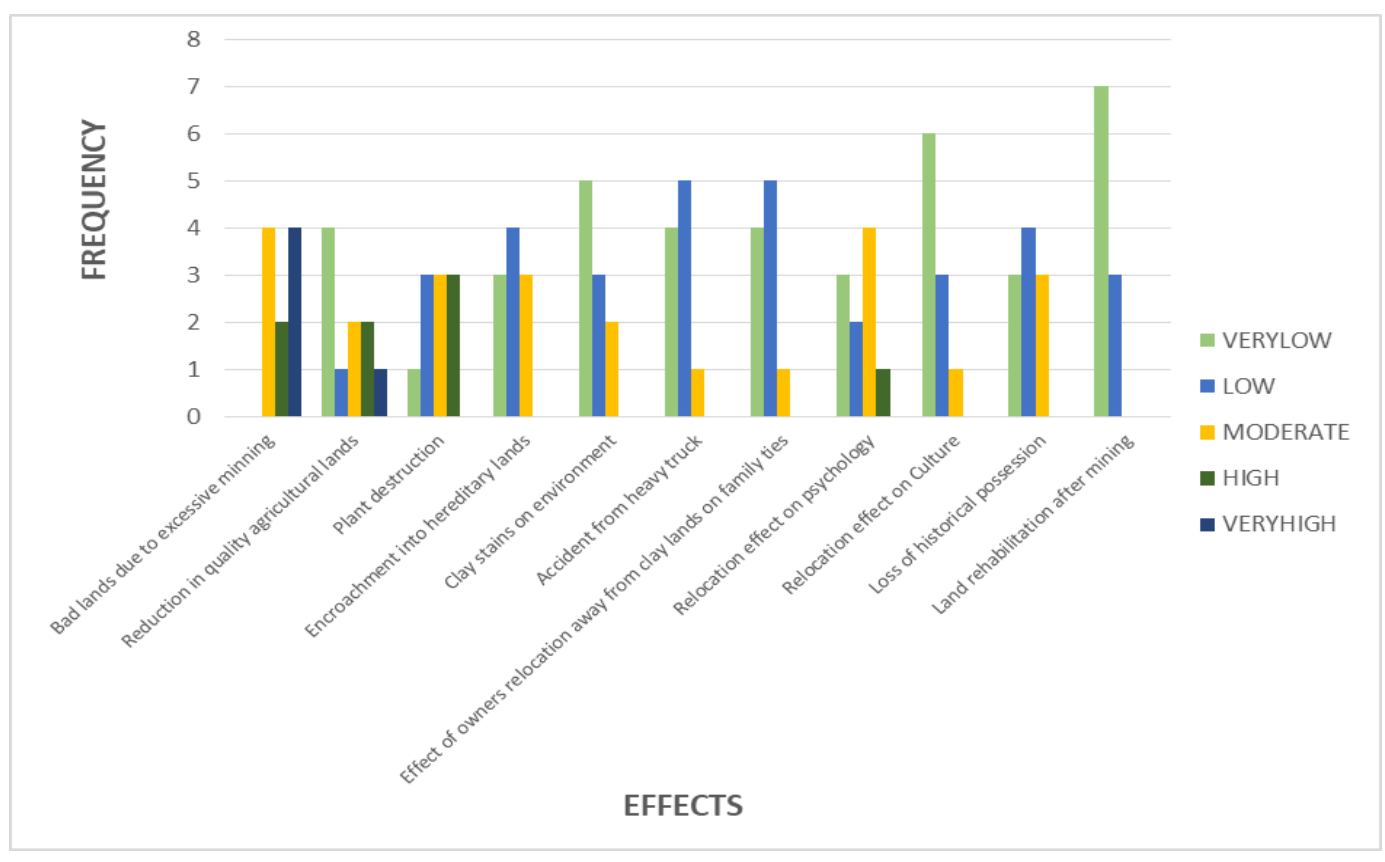

Fig. 3 Distribution of effect of Clay exploration on the society.

Figure 3 above reveals the effect of clay exploration on the society. The effect is then ranked according to their mean item score. From the survey, badlands due to excessive mining is the notable highest overall effects that clay exploration poses to the society with a mean score of (4.0). Plant destruction and Reduction in quality 
agricultural lands were ranked next with an estimated mean score of (2.8) and (2.5) respectively. Land rehabilitation after mining was neglected in the clay exploration process as noticed by the respondents. Relocation effects and encroachment into hereditary lands were ranked low.

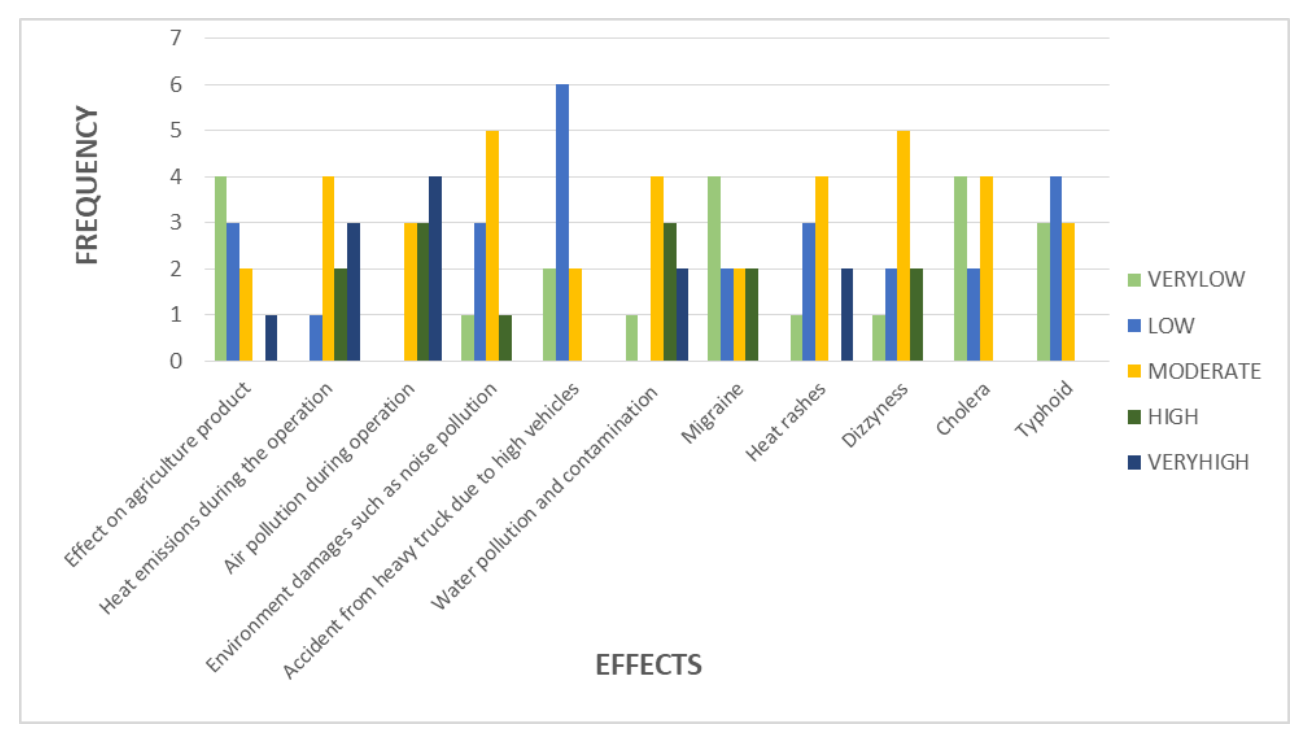

Fig. 4 Distribution of effect of Clay Pot industries on the society.

Figure 4 above reveals the effect of clay pot industries on the society. The effect is then ranked according to their mean item score. From the survey, Air pollution and heat emissions during operation ranked highest in the overall effects that clay pot industries pose to the society with a mean score of (4.1) and (3.7). Water pollution and contamination ranked next with an estimated mean score of (3.5). Health issues related to the existence of clay pot industries in societies were ranked low.

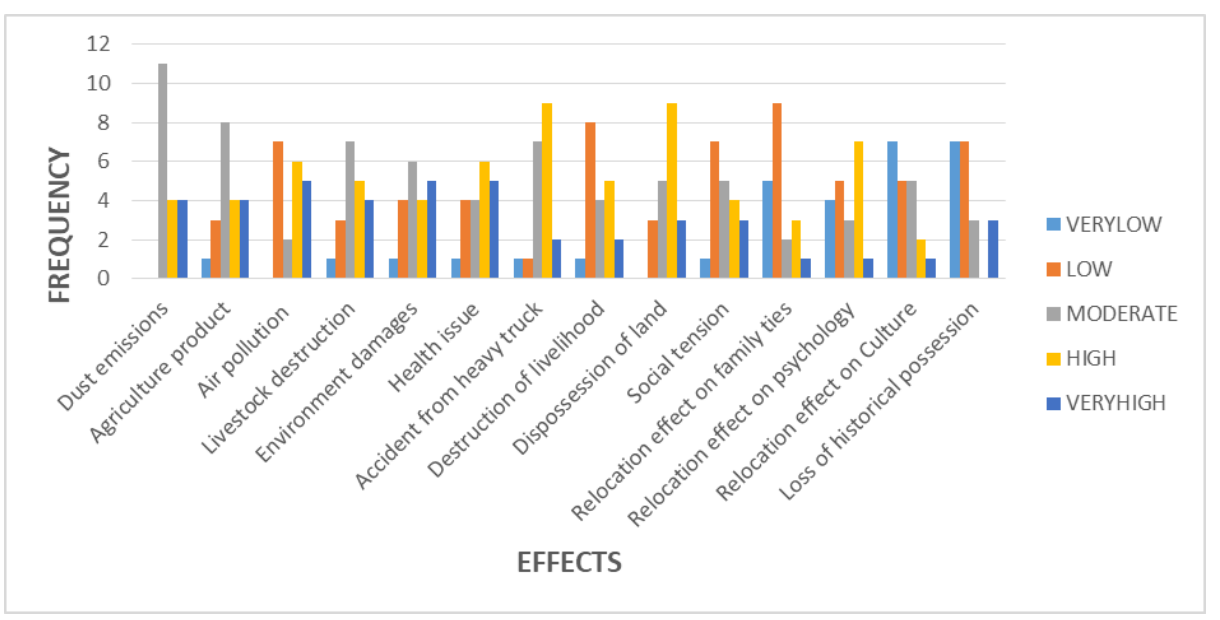

Fig. 5 Distribution of effect of Cement industries on the society. 
Figure 5 above reveals the effect of cement on the people living close to the factory. The effect is then ranked according to their mean item score. From the survey, dust emission is the notable highest overall risk cost factor that individual would have to do with over the entire life of the project with a score of (3.63). An estimated score of (3.60) was seen as the second notable effect for the dispossession of land from the cement factory, an estimated score of (3.5) was seen as the third with both effect caused by health issue and accident from heavy truck respectively.

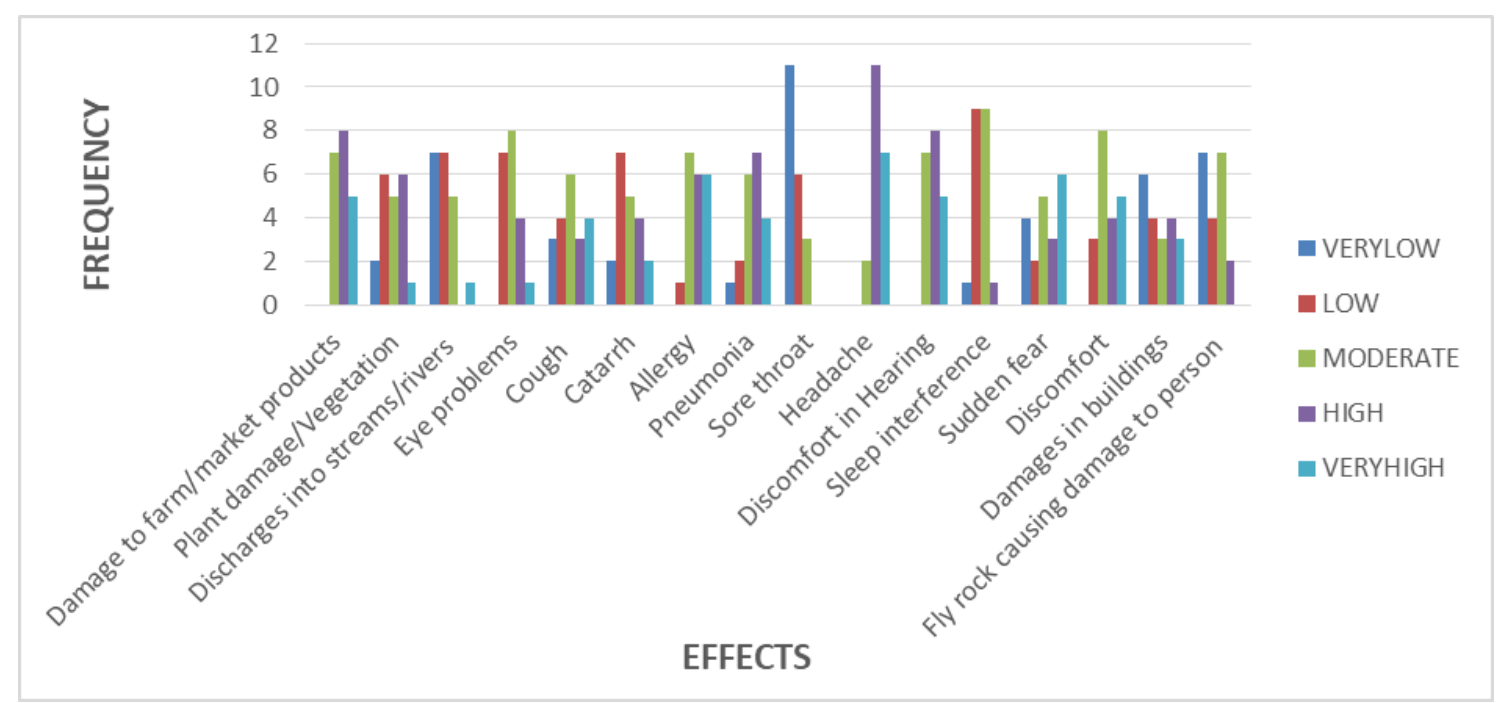

Fig 6 Distribution of effect of Quarries on the society.

Figure 6 above reveals the effect of quarry plant on the people living close to the plant. The effect is then ranked according to their mean item score. From the survey, headache is the notable highest overall effects that individual would have to do with over the entire life of the project with a score of (4.25). An estimated score of (3.90) was seen as the second notable effect from the quarry for both Damages to farm/market products and Discomfort in Hearing. Effect resulting from Fly rock causing damage to person, Discharges into streams/rivers and Sore throat are ranked with the lowest mean score of 2.20, 2.05, and 1.6 respectively.

\subsection{Comparison of Life Cycle Cost}

Having assessed the environmental impact of the three materials at production, the estimated Client and User cost are detailed below for a comparison of life cycle cost of the materials.

Table 9. Life Cycle Cost of Concrete, Hollow clay pot and Polystyrene slab.

\begin{tabular}{llll}
\hline & Concrete & Hollow clay pot & Polystyrene \\
\hline Client Cost & $59,700.68$ & $42,358.34$ & $46,125.65$ \\
User Cost & $34,284.99$ & $39,058.66$ & $37,132.71$ \\
Total & $93,985.67$ & $81,417.00$ & $83,258.36$ \\
\hline
\end{tabular}

In Table 9 above, the life cycle cost of a Hollow clay pot slab is the lowest followed by Polystyrene slab and then Concrete slab. The life cycle cost of Hollow clay pot slab is $2.26 \%$ lesser than the life cycle cost of a Polystyrene slab and $15.44 \%$ lesser than the life cycle cost of a Concrete Slab. The life cycle cost of a Polystyrene slab is $2.21 \%$ higher than the life cycle cost of Hollow clay pot slab and $12.88 \%$ lesser than the life cycle cost of a concrete slab. The life cycle cost of a concrete slab is $13.37 \%$ higher than the life cycle cost of a Hollow clay pot slab and $11.41 \%$ higher than the life cycle cost of a Polystyrene slab.

In a life cycle cost analysis, if the difference between the NPV of alternatives is less than 10 percent, then such alternatives are considered similar or equivalent [12]. This means that although the life cycle cost of Hollow clay pot slab ranked lowest, it is similar or equivalent to Polystyrene slab.

\subsection{Sensitivity Analysis.}

Uncertainty characterizes many of the input parameters in all appraisal process. The sensitivity analysis 
should examine the effect of variability in the main input parameters for the analysis of the overall results. This is done by performing the analysis over a range of possible values of a particular parameter under testing while holding all other parameters constant. This analysis can give the decision-maker a better representation of the comparison, and it can rule out bias toward certain alternatives to some extent [12].

The significant parameters that were tested for sensitivity in the analysis are the discount rate and the analysis period.

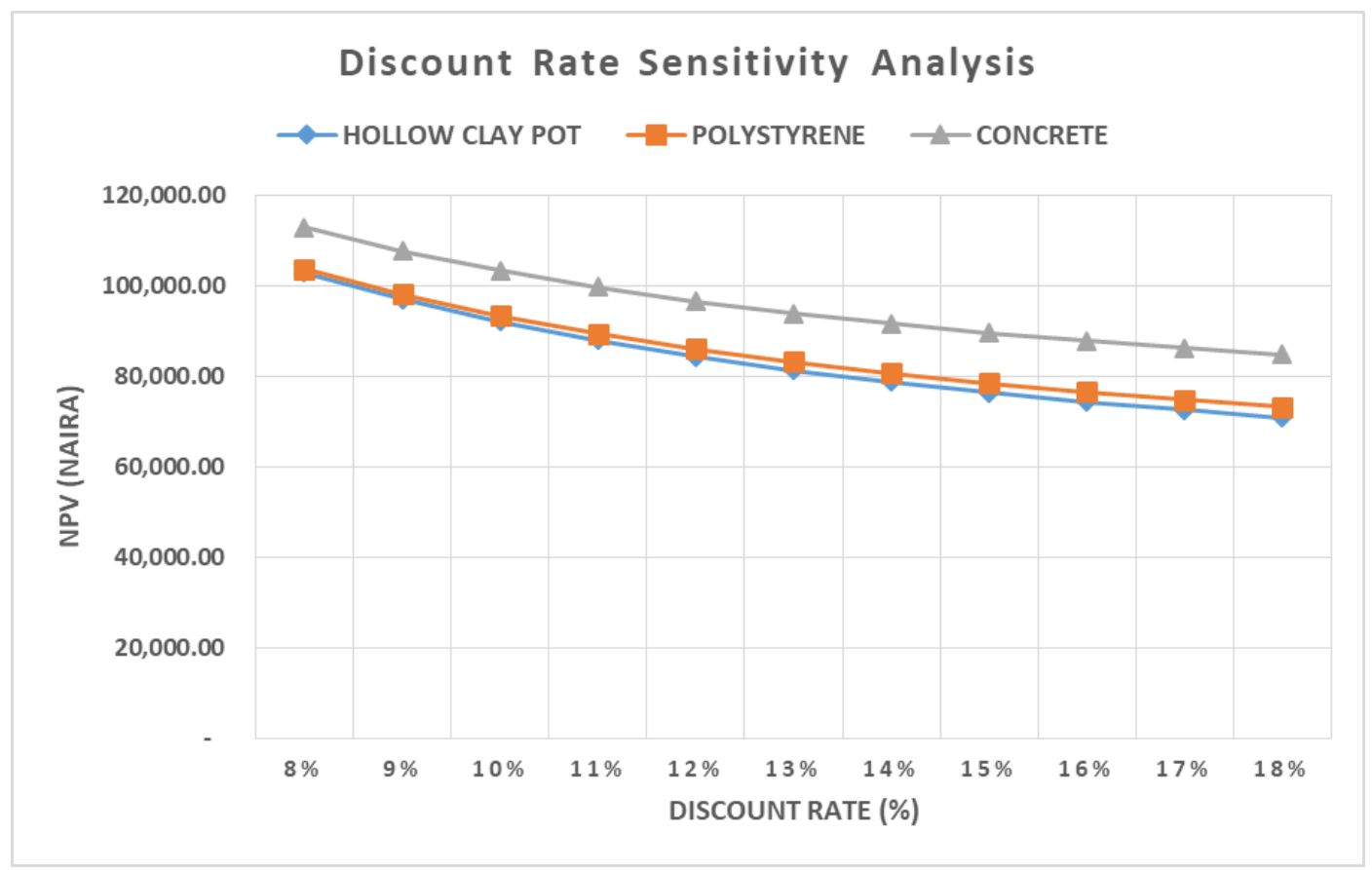

Fig. 7 Discount Rate Sensitivity Analysis Graph.

In Figure 7, the sensitivity analysis of the discount rate is conducted. The graph depicts a close distance between the NPV of Hollow clay pot slab and Polystyrene slab and the wide gap in relation to the NPV of the concrete slab.

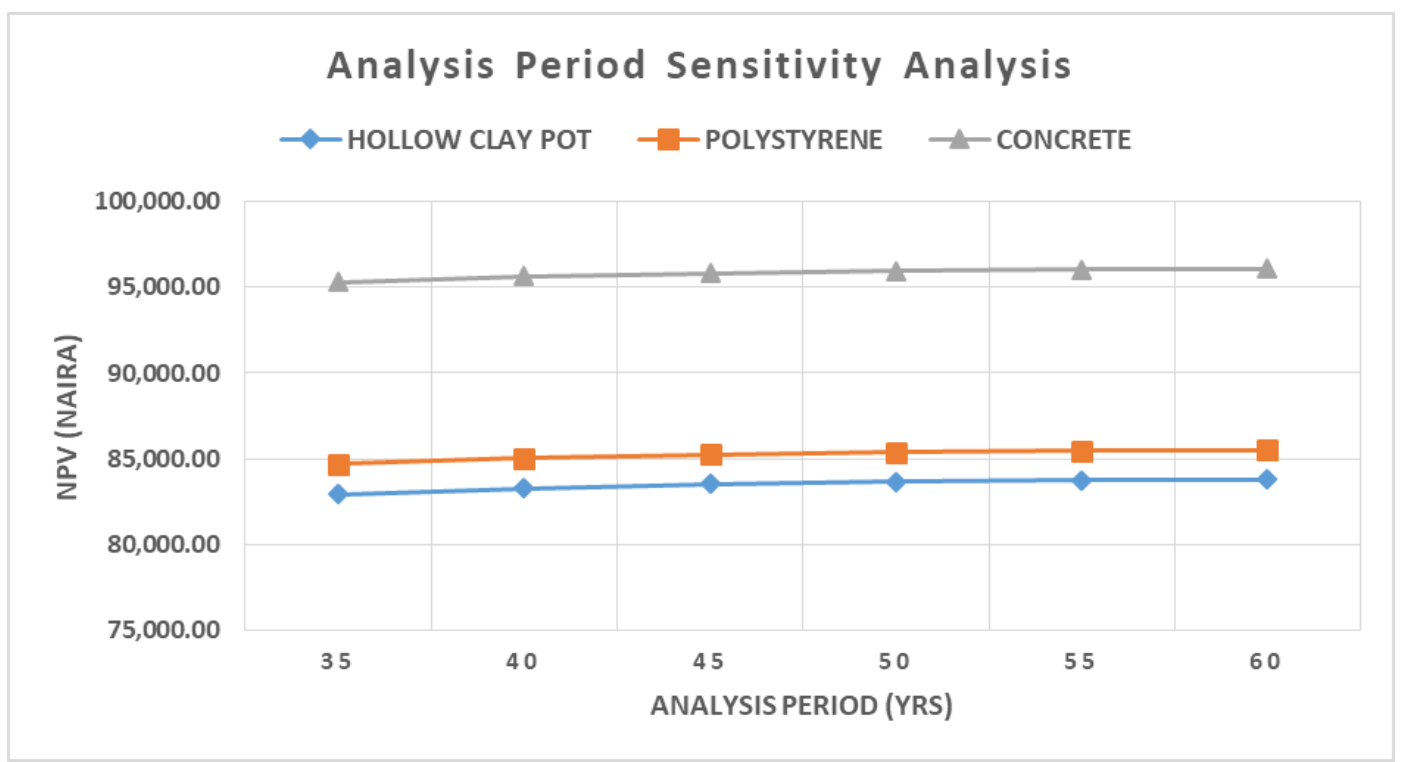

Fig. 8 Analysis Period Sensitivity Analysis Graph.

In Figure 8, the sensitivity analysis of the analysis period is conducted. The margin between the line of the Hollow clay pot and Polystyrene does not intercept at any point while that of Concrete differs with a wide margin. 


\section{Conclusion}

After an extensive and detailed study into the life cycle of a typical Polystyrene, Hollow clay pot, and

Concrete slab and the assessment of the impact of production on the society, the following conclusions are made

- The client cost of a Hollow clay pot slab is lower than that of a Polystyrene slab and a Concrete slab while that of Polystyrene slab is lower than the client cost of a concrete slab.

- The user cost of a typical Concrete slab is lower than that of a Polystyrene slab and a Hollow clay pot while that of a Polystyrene slab is lower than that of a concrete slab.

- The greatest effect a Polystyrene production pose to the environment is environment waste and the gas flaring from crude oil production. Polystyrene is a product of crude oil and as such bears the effect of crude oil production.

- Badlands after mining and Air pollution during production are the greatest effect posed by the exploration of clay and production of Hollow clay pot on the society.

- Dust emission from production and transfer of cement and Health rel.ated issues from the operations of a quarry pose the greatest environmental impact of a concrete when considering the constituent elements and their production.

- The life cycle cost of a Hollow clay pot is the lowest while the Polystyrene slab is lesser than the Concrete slab. Since the difference between the life cycle cost of the Hollow clay pot and Polystyrene is less than 10\%, in life cycle cost analysis, if the difference between the NPV of alternatives is less than 10 percent, then such alternatives are considered similar or equivalent.

- Hollow clay pot and Polystyrene serve as a better alternative for the commonly used Concrete and should, therefore, be adopted for slab construction.

\section{References}

1. Murty, C. V. R. (2003). How do Earthquakes affect Reinforced Concrete Buildings? Indian Institute of Technology, India.

2. ACI 302.1R (1996). Guide for concrete floor and slab construction. Report of the ACI Committee 302, 1R, USA

3. Ogundiran I. A. \& Adedeji, Y. M. D. (2014). Sustainable Construction: Comparative Advantages of Expanded Polystyrene (EPS) Fascia in Housing Delivery in Nigeria. Civil and Environmental Research. ISSN 2224-5790 Vol.6, No.10, 2014.

4. Visser, W. D. (2009). Which type of slab is the most effective solution to concrete structures? BSc. Research. Faculty of Engineering, BEIT, University of Pretoria. October 2009.

5. Ibrahim, D., Bankole, O. C., Ma'aji, S. A., Ohize, E. J. \& Abdul, B. K. (2013). Assessment of the Strength Properties of Polystyrene Material used in Building Construction in Mbora District of Abuja, Nigeria. IJERD, 6(12), May 2013, PP. 80-84.

6. Goodier, K. (2009). "Making and Using an Expanded Plastic" New Scientist 240:706.

7. Bajracharya, R. M., Lokuge, W. P., Karunasena, W., Lau, K.T. \& Mosallam, A. S. (2012). Structural Evaluation of Concrete Expanded Polystyrene Sandwich Panels for Slab Applications. Conference: 22nd Australasian Conference on the Mechanics of Structures and Material. December 2012.

8. Adenuga, O. A. \& Sotunbo, G. (2014). An Assessment of Time Variation in Solid and Hollow Floor Construction in Lagos State. Organization, Technology and Management in Construction Journal. 6(1)2014, pp $985-993$.

9. Lai Tina. (2010). Structural behaviours of bubble deck slabs and their applications to light weight bridge deck. MSc Thesis: Department of Civil and Environmental Engineering, MIT.

10. Singh, P. \& Scanlon, A. (2013). Concrete in Residential Construction. Research Series Report No. 110. Pennsylvania Housing Research Center, Penn State University.

11. UNESCO-NIGERIA. (2008). Technical \& Vocational Education Revitalisation Project-Phase II. Technical notes on Building Construction.

12. Ozbay, K., Parker, N. A., Jawad, D. \& Hussain, S. (2003). Guidelines for Life Cycle Cost Analysis. Report for Federal Highway Administration.

13. Alexandra, S. \& Ferreira Real, C. (2010). Contribution of Life Cycle Cost analysis to design Sustainability in Construction. Instituto Superior Técnico, Universidade Técnica de Lisboa

14. Bowyer, J., Fernholz, K., Bratkovich, S., Howe, J., Stai, S. \& Frank, M. (2013). Life Cycle Cost Analysis of Non-Residential Buildings. A report by Dovetail Partners, Inc. 
15. Bribián, I. Z., Capilla, A., and Usón A. A.(2010) LCA on building materials: Comparative analysis of energy and environmental impacts and evaluation of the eco-efficiency improvement potential. Building and Environment 46 (5), 113-1140, 2011.

16. Dosumu, O. S \& Adenuga, O. A. (2013). Assessment of Cost Variation in Solid and Hollow Floor Construction in Lagos State. Journal of Design and Built Environment, Vol.13, December 2013.

17. Sjunnesson, J. (2005). Life cycle assessment of Concrete. MSc Thesis: Department of Technology and Society, Environmental and Energy Systems Studies, Lund University. September 2005.

18. Huntzinger, D. N., \& Eatmon, T. D. (2009). A life-cycle assessment of Portland cement manufacturing: comparing the traditional process with alternative technologies. Journal of cleaner production, 17(7), 668-675.

19. Chen, C., Habert, G., Bouzidi, Y., \& Jullien, A. (2010). Environmental impact of cement production: detail of the different processes and cement plant variability evaluation, Journal of Cleaner Production, 18 (2010) pp478-485.

20. Moedinger, F. (2005). Sustainable Clay Brick Production - A Case Study. Presented at The 2005 World Sustainable Building Conference, Tokyo, 27-29 September 2005

21. Fuyane, B. F., Atlhopheng, J. R., Mulale, K. (2013). Impact Analysis of Informal Brick Production on the Environment: Gaborone Dam Area, Botswana. IJSTR. 2(9), p 73-78. September 2013.

22. Kumbhar, S., Rao, B., Kulkarni, N. \& Rao, A. B. (2014). Environmental Life Cycle Assessment of Traditional Bricks in Western Maharashtra, India. 4th, ICAER 2013. Energy Procedia, Volume 54 (2014) p $260-269$.

23. Skinder, B. M., Sheikh, A. Q., Pandit, A. K. \& Ganai, B. A. (2014). Brick kiln emissions and its environmental impact: A Review. Journal of Ecology and the Natural Environment. Academic Journal. 6(1), pp. 1-11, January 2014 ISSN 2006-9847.

24. AFPR (2009). Expanded Polystyrene Packaging Environmental Profile Analysis. Alliance of Foam Packaging Recyclers, 1298 Cronson Boulevard, Suite 201 Crofton.

25. BPF EPG (2013). Expanded Polystyrene (EPS) and the Environment. British Plastics Federation Expanded Polystyrene Group.

26. EPSASA (2013). Guide to building with Expanded polystyrene (EPS) in compliance with SANS 204. Energy efficiency and environmental impact. Expanded Polystyrene Association of South Africa.

27. EUMEPS (2013). Sustainable Construction with EPS Insulation. Greenpeace Energy Revolution (2007)

28. Ede, A. N., Salami, A. J., Olukanni, D. O., Ogbiye, A. S., Omole, D. O. \& Akinwumi, I. I. (2014). Life Cycle Cost Evaluation of using Expanded Polystyrene for Residential Buildings, IJESM, ISSN: 22775528 Vol. 4, Issue 2: 2014, 11-15

29. EPSMA (2009). Expanded Polystyrene reduces global warming, A new perspective on EPS. EPS Molders Association 1298 Cronson Blvd., Suite 201 Crofton.

30. Cofala, J., Amann, M., Gyarfas, F., Schoepp, W., Boudri, J. C., Hordijk, L., Kroeze, C., Li, J. F., Lin, D., Panwar, T. S. \& Gupta, S. (2004). Cost-effective control of SO2 emissions in Asia. Journal of Environment Management, 72: 149-161.

31. Shakir, A. A. \& Mohammed, A. A. (2013). Manufacturing of Bricks in the Past, in the Present and in the Future: A state of the Art Review. IJAAS, Vol. 2(3), September 2013, pp. 145 156 ISSN: 22528814.

32. Mehta, P. K., (2001). "Reducing the Environmental Impact of Concrete" Concrete International, October 2001 ed., page 61-66

33. BS6472 (1992). Guide to Evaluation of human exposure to vibration in buildings (1 Hz to $80 \mathrm{~Hz}$ ). BSI, London. February 1992.

34. CSRI (2016). Vibration and Sound Control in Reinforced Concrete Buildings. Concrete Reinforcing Steel Institute - CRSI Technical Note ETN-B-3-16, Schaumburg, Illinois.

35. CCAA (2009). Sound Insulation Properties of Concrete Walls and Floors. Cement Concrete \& Aggregates Australia. St Leonards NSW, Australia. March 2009.

36. ABCB (2016). Sound Transmission and Insulation in Buildings. Australian Building Codes Board. Australian Government and States and Territories of Australia 2016. Canberra ACT.

37. UPONOR (2011). Complete Design Assistance Manual (CDAM) Seventh Edition. Chapter 7: Heat Loss Considerations and Calculations. Uponor, Inc., Apple Valley, USA.

38. LSP (2002). Moisture Effects on Flooring Systems. Life Science Products, Inc. January, 2002. 